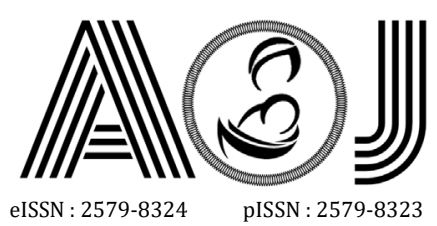

\title{
RESEARCH
}

\section{The Effect of Oral Albumin Intake on Serum Albumin Levels in Preeclamsia Patients With Hypoalbuminemia in RSUP Dr. M. Djamil Padang}

Irwin Fitriansyah $^{1}$, Dovy Djanas ${ }^{2}$, Hafni Bachtiar ${ }^{3}$

Affiliation author: 1. Obstetrics and Gynecology, Faculty of Medicine, Andalas University, Bangka Tengah District Hospital Bangka Belitung; 2. Sub Division of Maternal Fetal Medicine, Obstetrics and Gynecology Department, Faculty of Medicine, Andalas University, Dr. M. Djamil Central General Hospital Padang; 3. Public Health Department, Faculty of Medicine, Andalas University Padang Correspondence to: Irwin Fitriansyah, email: irwinfitriansyah@gmail.com, Hp: 085268862364

\section{Abstract}

Introduction : Albumin main function is maintaining the plasma colloid oncotic pressure. Preeclampsia cause a decrease in serum albumin in the pregnant woman. Low albumin levels increase mortality, longer wound healing and longer hospital stays. The intake of oral albumin is expected to be effective in increasing the level of albumin in the blood.

Objective : To determine the effect of freeze dryer method intake compared to liquid snakehead fish extract in patients with preeclampsia and hypoalbuminemia.

Material and methods : Using pre and post-test control group design.The total sample was 38 patients with severe preeclampsia with hypoalbuminemia, divided into control and intervention groups. Control was given the intake of liquid snakehead fish extract, in the intervention was given the Freeze dryer method. The research data were analyzed using the Mann Whitney test method and the Wilcoxon test.

Results : In the intervention group the mean pretest albumin level was $2.66 \pm 0.17 \mathrm{gr} / \mathrm{dl}$ and on the $4^{\text {th }}$ day it was $3.13 \pm 0.16 \mathrm{gr} / \mathrm{dl}(\mathrm{p}=0.000)$. In the control group the mean pretest albumin level was 2.72 $\pm 0.15 \mathrm{gr} / \mathrm{dl}$ and on the 4 th day it became $3.06 \pm 0.14 \mathrm{gr} / \mathrm{dl}(\mathrm{p}=0.000)$. On the 4th day after treatment, the increase in serum albumin levels in the intervention group was $0.47 \pm 0.19 \mathrm{gr} / \mathrm{dl}$; whereas in the control group was $0.34 \pm 0.10 \mathrm{gr} / \mathrm{dl}$ with a value of $p=0.031(p<0.05)$.

Conclusion : The freeze dryer method (freeze dryer method) for the Cork Fish Extract resulted in a higher increase in albumin levels than the liquid snakehead fish extract.

Keywords: Preeclampsia, Hypoalbuminemia, freeze dryer method of Snakehead Fish Extract

Received : October $18^{\text {th }}, 2020$ 


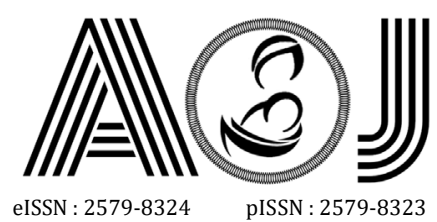

eISSN : 2579-8324
pISSN : 2579-8323

Editorial Room Andalas Obstetrics and Gynecology Journal, $3^{\text {rd }}$ floor of KSM of Obstetrics and Gynecology, RSUP DR. M. Djamil Padang, Jl. Perintis Kemerdekaan Padang, Sumatera Barat 25127

Website:

http://jurnalobgin.fk.unand.ac.id/index.php/JOE

\section{INTRODUCTION}

Preeclampsia is a multi-organ disorder that occurs in pregnant women with high blood pressure which is still difficult to predict in human pregnancy. This is associated with significant maternal and fetal morbidity and mortality worldwide. ${ }^{1,2}$ Although there has been a decrease in the incidence of maternal mortality due to preeclampsia in more developed countries, preeclampsia is still one of the most common reasons for this. mortality of pregnant women especially in developing countries. ${ }^{1.3}$

Renal blood flow and glomerular filtration rate during normal pregnancy are increased compared to the nonpregnant state. With the onset of hypertension in pregnancy, blood perfusion in the kidneys and glomerular filtration rate is impaired so that it varies variably, as is the case with glomerulopathy, there is an increase in glomerular permeability to plasma proteins, especially albumin, so that a lot of albumins is released into the urine

During normal pregnancy, there is a decrease in albumin levels, especially during the third trimester. This process is thought to be caused by the increased need for protein and its use by the fetus. In patients with preeclampsia, the reduction in albumin levels is partly the result of excess albumin excretion and is accompanied by a decrease in IgG, an increase in IgE and a1globulin. There is also a relative increase in globulin in the third trimester and a decrease in all circulating proteins in people with preeclampsia.

Often found in clinical practice, women after cesarean section diagnosed with severe preeclampsia and eclampsia with low laboratory albumin levels. Hypoalbuminemia in severe preeclampsia and eclampsia is caused by proteinuria causing further complications such as edema and damage to capillary endothelial cells. ${ }^{4}$

Low colloid oncotic pressure due to loss of albumin through urine and increased interstitial capillary permeability results in fluid build-up in the interstitial tissue and lungs. Preeclampsia is associated with decreased renal blood flow and glomerular filtration and increased serum creatinine. ${ }^{1,3,4}$

Hypoalbuminemia is a condition where there is a decrease in serum albumin to below $3.5 \mathrm{~g} / \mathrm{dl}$, but it appears clinically significant when the serum albumin level is below $2.5 \mathrm{~g} /$ dl. ${ }^{5,6}$ The condition of low serum albumin levels is a risk factor and can be used as a parameter. morbidity and mortality regardless of the disease involved. ${ }^{5,6,7}$ In addition, patients with low albumin levels have higher mortality, longer wound healing and longer hospital stay.

Albumin is a protein with a molecular weight of $65,000-69,000$ Daltons consisting of 585 amino acids with 17 disulfide bonds that link sulfur-containing amino acids. Albumin is synthesized in liver cells and is the main component of blood plasma proteins with normal albumin concentrations ranging from 3.5 - $5.0 \mathrm{~g} / \mathrm{dl}^{3}$ This protein is synthesized by hepatocytes and immediately excreted into the bloodstream at a rate of about $10 \mathrm{~g}$ to $15 \mathrm{gr}$ 


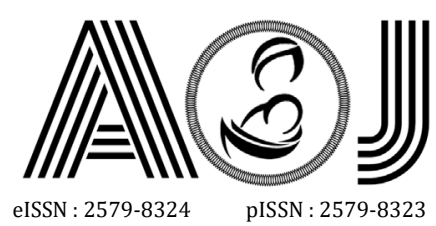

eISSN : 2579-8324
pISSN : 2579-8323

per day. Albumin is very little stored in the liver, and most of it is quickly excreted into the bloodstream. ${ }^{4.5}$

Serum albumin functions as a major modulator of oncotic pressure in blood plasma and as a carrier of endogenous and exogenous materials (eg drugs) to target organs. In clinical practice, serum albumin is measured as one of the basic laboratory tests. Albumin is also an important colloid solution given to patients requiring fluid resuscitation. 4,5,6

Albumin is quantitatively the most important antioxidant in circulation and has important enzymatic abilities in the body. The ability of this protein to bind substances and as a transporter for endogenous and exogenous substances is an object of interesting research until now. Recent studies have provided a wealth of information on the location and structure of the binding sites for albumin. This information on albumin structure is also important in the manufacture of new drugs aimed at avoiding bonding or taking advantage of the binding ability.

Snakehead fish (Ophicephalus striatus) is known to contain important compounds for the human body, including high enough protein, fat, water, minerals. Snakehead fish in 100 grams contains albumin $6.2 \mathrm{gr}, 69$ calories, 1.7mg Zinc, $3 \mathrm{mg}$ Glutamate, $1.1 \mathrm{mg}$ arginine and $3.2 \mathrm{mg}$ BCAA (Brain Chain Amino Acid) consisting of leucine, isoleucine and valine, fish protein which has $95 \%$ digestibility. $6,7,8$

Various studies mention the significant benefit of albumin administration in hypoalbumin patients in reducing morbidity and mortality. Giving albumin to patients with severe preeclampsia and eclampsia will repair endothelial damage, restore low central venous pressure to normal with improved kidney function.

\section{METHODS}

Using pre and post-test control group design, conducted in Obsgyn department of RSUP dr. M. Djamil Padang, West Sumatera. This study was done from June 2019 until February 2020. The total sample was 38 patients with severe preeclampsia with hypoalbuminemia, divided into control and intervention groups. Control was given the intake of liquid snakehead fish extract, in the intervention the Freeze dryer method was given. The research data were analyzed using the Mann Whitney test method and the Wilcoxon test.

Before the study was conducted, ethical clearance was submitted to the Ethical Committee of Medical Faculty Andalas University and had been approved for ethical clearance. 


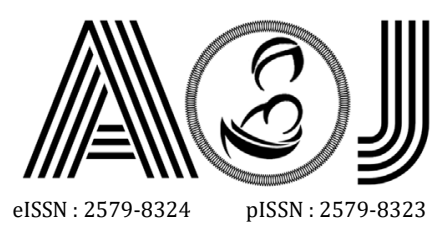

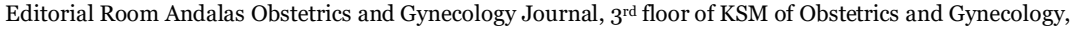
RSUP DR. M. Djamil Padang, Jl. Perintis Kemerdekaan Padang, Sumatera Barat 25127

Website:

http://jurnalobgin.fk.unand.ac.id/index.php/JOE

\section{RESULTS}

\section{Study Respondents Characteristics}

Characteristics of study respondents consisted of maternal age, level of education, gravidity, BMI before pregnancy, and BMI at pregnancy, which could be seen in Table 1.

Table 1. Respondents Characteristics

\begin{tabular}{lccc}
\hline $\begin{array}{c}\text { Respondents Characteristics } \\
\text { (mean } \pm \text { SD) }\end{array}$ & \multicolumn{2}{c}{$\mathbf{N}$} & \\
\cline { 2 - 3 } & $\begin{array}{c}\text { Intervension } \\
(\mathbf{n = 1 9 )}\end{array}$ & $\begin{array}{c}\text { Control } \\
(\mathbf{n = 1 9 )}\end{array}$ & p value \\
\hline Maternal Age (years) & $31,4 \pm 6,3$ & $31,3 \pm 6,3$ & 0,965 \\
Gravitas & $2,9 \pm 1,4$ & $3,4 \pm 1,9$ & 0,525 \\
BMI (kg/m2) & $23,7 \pm 2,3$ & $23,9 \pm 5,2$ & 0,237 \\
Systolic BP (mmHg) & $171,1 \pm 15,6$ & $176,3 \pm 13,0$ & 0,251 \\
Diastolic BP(mmHg) & $108,4 \pm 13,4$ & $109,5 \pm 9,7$ & 0,797 \\
Urine Protein (Kualitatif) & $2,6 \pm 0,6$ & $2,3 \pm 0,7$ & 0,195 \\
Albumin pretest (gr/dl) & $2,66 \pm 0,17$ & $2,72 \pm 0,15$ & 0,208 \\
\hline
\end{tabular}

Based on Tabel 1, it could be seen that respondent characteristic between intervention and control group was homogeny, there were no significant relationship between maternal age, gravidity, BMI, Systolic BP, Diastolic BP, Urine Protein, and Albumin level in pretest, which is shown from the $p$-value above 0.05

\section{The effect of freeze dryer method intake compared to liquid snakehead fish extract in} patients with preeclampsia with hypoalbuminemia against serum albumin level

Before Statistical analysis, First, the normality analysis of the data distribution was carried out using the Shapiro Wilk test, which results are shown as follows.

Table 2. The results of the data distribution normality analysis

\begin{tabular}{lcc}
\hline \multirow{2}{*}{ Albumin Level } & \multicolumn{2}{c}{$p$-value shapiro wilk test } \\
\cline { 2 - 3 } & Intervension $(\mathbf{n = 1 9 )}$ & Control $(\mathbf{n}=\mathbf{1 9})$ \\
\hline Pretest (H0) & 0,004 & 0,016 \\
- 3 days after Intervension $(\mathrm{H} 4)$ & 0,007 & $0,337^{*}$ \\
- Difference HO - H4 & 0,030 & 0,026
\end{tabular}

Note: ${ }^{*}=$ normal data distribution $(p>0,05)$

Based on Table 2, it is known that the results of the normality analysis of data distribution with the Shapiro Wilk test show that the normal distribution of albumin levels is shown at albumin levels 3 days after treatment in the control group ( $p>0.05$ ), while other albumin levels (before treatment in both groups, albumin levels 3 days after treatment in the intervention group, as well as data on the difference in albumin levels between $\mathrm{HO}$ and $\mathrm{H} 4$ ) showed an abnormal distribution of data $(p<0.05)$. 


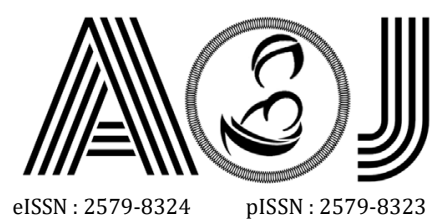

eISSN : 2579-8324
pISSN : 2579-8323
ANDALAS OBSTETRICS AND GYNECOLOGY JOURNAL

Address for Correspondence:

Editorial Room Andalas Obstetrics and Gynecology Journal, $3^{\text {rd }}$ floor of KSM of Obstetrics and Gynecology,

RSUP DR. M. Djamil Padang, Jl. Perintis Kemerdekaan Padang, Sumatera Barat 25127

http://jurnalobgin.fk.unand.ac.id/index.php/JOE

Next, whether the treatment given to the intervention and control groups affected the albumin levels of preeclamptic and hypoalbuminemic respondents, an analysis was carried out by comparing the pretest (baseline) albumin levels with the posttest (after treatment) albumin levels. Statistical analysis was performed using the Wilcoxon test because the data distribution normality requirements were not met.

Table 3. Analysis of the effect of intake of Freeze dryer method and liquid snakehead fish extract on serum albumin levels on day 4

\begin{tabular}{ccccc}
\hline \multirow{2}{*}{ Group } & \multicolumn{2}{c}{ Albumin (Mean \pm SD) } & Z & p-value \\
\cline { 2 - 3 } & Pretest & Posttest (4th day) & & \\
\hline Intervention & $2,66 \pm 0,17$ & $3,13 \pm 0,16$ & $-3,842$ & 0,000 \\
- Control & $2,72 \pm 0,15$ & $3,06 \pm 0,14$ & $-3,863$ & 0,000 \\
\hline
\end{tabular}

Table 3 shows that the results of the comparison analysis of pretest-posttest albumin levels with the Wilcoxon test obtained a $Z$ value of -3.842 and $p=0.000(p<0.05)$, meaning that there was a significant difference in albumin levels between before and 3 days after giving the Freeze dryer method and also similar to the provision of liquid snakehead fish extract.

Furthermore, to determine the comparison of the effect of both administrations, an analysis was carried out on the data on the difference between pretest serum albumin levels ( $\mathrm{HO}$ ) and 3 days after treatment ( $\mathrm{H} 4)$. Statistical analysis was performed using the Mann Whitney test because the normality requirements of the data distribution were not fulfilled. The results of the Mann Whitney analysis are shown in Table 4

Table 4. Comparative analysis of the effect of intake of Freeze dryer method and liquid snakehead fish extract on serum albumin levels

\begin{tabular}{ccccc}
\hline \multirow{2}{*}{$\begin{array}{c}\text { Albumin Different } \\
(\text { Mean } \pm \text { SD) }\end{array}$} & \multicolumn{2}{c}{ Group } & Z & p-value \\
\cline { 2 - 3 } & Intervention $(n=19)$ & Control & & \\
\hline 0 day -4 th day & $0,47 \pm 0,19$ & $0,34 \pm 0,10$ & $-2,161$ & 0,031
\end{tabular}

On the 4th day after treatment, the increase in serum albumin levels in the intervention group was $0.47 \pm 0.19 \mathrm{gr} / \mathrm{dl}$; whereas the increase in serum albumin levels in the control group was $0.34 \pm 0.10 \mathrm{gr} / \mathrm{dl}$. The Mann-Whitney test resulted in a Z value of -2.161 and $p=0.031$ ( $p$ $<0.05)$, meaning that there was a difference in the effect of the Freeze dryer method and liquid snakehead fish extract for 3 days on serum albumin levels in preeclamptic respondents with hypoalbuminemia. The freeze dryer method also produced higher albumin levels than liquid snakehead fish extract. 


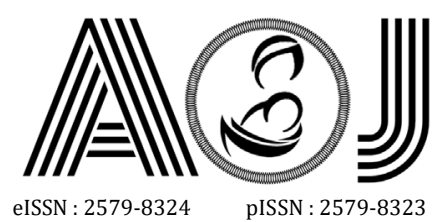

eISSN : 2579-8324
pISSN : 2579-8323

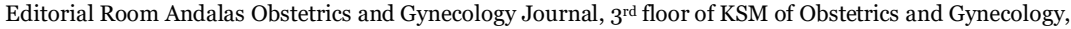
RSUP DR. M. Djamil Padang, Jl. Perintis Kemerdekaan Padang, Sumatera Barat 25127

Website:

http://jurnalobgin.fk.unand.ac.id/index.php/JOE

\section{DISCUSSION}

\section{The Effect of Oral Albumin Intake on Serum Albumin Levels in Patients with Preeclampsia} / Eclampsia with Hypoalbuminemia.

The results showed that on the 4th day after treatment, the increase in serum albumin levels in the intervention group was $0.47 \pm 0.19 \mathrm{gr} / \mathrm{dl}$; whereas the increase in serum albumin levels in the control group was $0.34 \pm 0.10 \mathrm{gr} / \mathrm{dl}$, meaning that there was a difference in the effect of giving Vip Albumin sachets and liquid snakehead fish extract for 3 days on serum albumin levels in preeclamptic respondents with hypoalbuminemia. The mechanism for increasing the serum albumin level of respondents in this study as previously described is through increasing the total energy intake or the direct effect caused by supplementation and the loss of one of the triggers for the release of protein from the body. Adequate nutritional support can improve visceral protein levels in the body which have been used as an energy source due to insufficient energy intake from food for the body in dealing with chronic inflammatory processes that occur. This result is similar to the results of research by Benny (2012) which states that blood albumin levels are more. Higher in the group that received extra snakehead fish albumin capsule compared to the group that did not receive snakehead fish extract albumin capsules. In this study, the albumin levels given were slightly different, due to the provision of research material in the form of liquid snakehead fish extract produced by the Nutrition section of dr. M.Djamil Padang, cannot be made only for research purposes, but also to meet the needs of other patients besides the study respondents who were included using the consecutive sampling method, being another obstacle to the availability of this material. However, from the results of statistical analysis of the results of the study, it did show a significant increase in albumin levels of all respondents.

A study by Siti, et al (2018) stated that giving a high-calorie and high-protein diet increased responder serum albumin levels by about $73 \%$. A diet high in calories and high in protein can aid in the recovery of preeclamptic patients. A good protein intake can meet the protein needs in the patient's body and help the remodeling process for damage that occurs in the endothelial tissue of blood vessels that occurs during preeclampsia. Research by Ruspita (2011) and Nugrahani (2007) states that a diet high in calories and high in protein with extra egg white is effective in increasing albumin levels in the blood. Protein is very important for the body because it acts as a source of energy, as a building block for the body and a regulator in the body, as well as for its benefits for the body to form new tissue and maintenance of existing tissue (replacing damaged tissue). In general, protein serves as a complement system, a source of nutrition that maintains the balance of intra and extracellular fluids, as a plasma buffer, the formation of antibodies, hormones, and transport of special substances. 


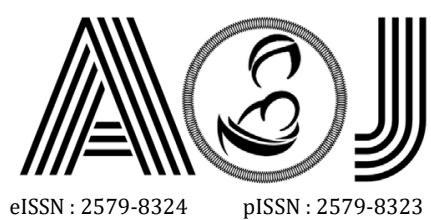

eISSN : 2579-8324
pISSN : 2579-8323

A study by Pattiha (2011) states that giving a diet high in calories and high in protein (TKTP) and extra snakehead fish albumin capsules is effective in increasing serum albumin levels in HIV / AIDS sufferers. Research by Mulyana et al (2017) states extra Ophiocephalus striatus can increase IGF-1 and Albumin levels in malnourished elderly patients. A study by Rosi (2008) states that the assessment of nutritional status is very important to use to assess the likelihood of calorie and protein malnutrition. In its application in the hospital, nutritional status assessment by anthropometry and biochemistry, namely by examining serum albumin levels. Levels of serum albumin and cholesterol can be predictors of death in hospital, infections, and length of stay. Research on post-surgical patients at Dr. Wahidin Sudorohusodo Makasar found that the administration of snakehead fish concentrate capsules for 10 days can increase the albumin levels of post-surgical patients by $0.75 \mathrm{mg} / \mathrm{dl}$. Provision of snakehead fish concentrate capsules for 10 days can accelerate wound healing which appears to decrease signs of infection more quickly. Provision of snakehead fish concentrate capsules can shorten the length of stay by 4 days.

\section{Effect of Oral Albumin Intake of Nano Freeze Dryer Technology on the increase in serum albumin levels}

In a study conducted by Kurniawati in 2014, giving albumin from pure snakehead fish extract with freeze dryer technology for 3 days could increase albumin levels by $1.26+0.30$ $\mathrm{mg} / \mathrm{dl}$. Snakehead fish (Ophicephalus striatus) is known to contain important compounds for the human body, including high enough protein, fat, water, minerals. Snakehead fish in 100 grams contains albumin 6.2 grams, 69 calories, $1.7 \mathrm{mg}$ Zinc, $3 \mathrm{mg}$ Glutamate, $1.1 \mathrm{mg}$ arginine, and $3.2 \mathrm{mg}$ BCAA (Brain Chain Amino Acid) consisting of leucine, isoleucine, and valine, the fish protein which has $95 \%$ digestibility. Protein in fish, apart from being a source of nutrition, also has functional properties that are important for health. Various properties of snakehead fish (Ophicephalus striatus) have been suggested, including antinociceptive function (Zakaria et al, 2012), accelerating wound healing (Baie \& sheikh, 2000), anti-inflammatory (Abedi et al, 2012), anti-hypertension through myofibril protein hydrolyzates (Ghassem, 2011), the high levels of albumin and $\mathrm{Zn}$ in extra snakehead fish have good health benefits, the albumin content of snakehead fish can increase albumin levels in human blood (Mustafa et al, 2012). A study by Aisyatussoffi (2013) stated that giving an extra $0.14846 \mathrm{ml} /$ day of snakehead fish for 14 days was able to regenerate $68.78 \%$ of Langerhans pancreas tissue and reduce blood glucose levels by $34.42 \%$.

According to Gibson (2015) snakehead fish is another alternative as a source of albumin because it is known to contain important compounds for the body, including high protein, fat, water, and minerals. Especially the mineral $\mathrm{Zn}$. Zn functions as an antioxidant 


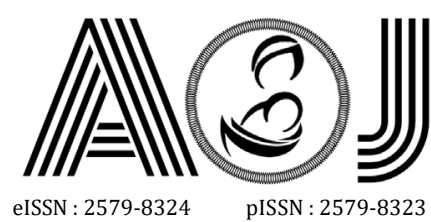

eISSN : 2579-8324
pISSN : 2579-8323

that protects cells, accelerates the wound healing process, regulates expression in lymphocytes and proteins, improves appetite, and stabilizes body weight.

In snakehead fish, there are types of amino acids isoleucine, leucine, and valine which are branched-chain amino acids (BCAAs). In the human body, BCAAs are amino acids that are synthesized in muscles, so the content of these amino acids shows that snakehead fish meat is beneficial for preventing damage. muscles and helps muscle growth. In addition, this substance plays a role in balancing hormone release and brain function. The high amino acid lysine is the difference between fish protein and protein from nuts. Lysine is an amino acid that acts as a precursor for the formation of carnitine, which is a stimulant for beta-oxidation processes in the body, so that cholesterol and fat levels in the body are low. Lysine also plays a role in the formation of collagen needed by skin and bones. In snakehead fish protein, there is also a fairly high non-essential amino acid (glycine). Glycine functions to accelerate wound healing, so the protein from snakehead fish is believed to help the wound healing process become faster. According to Lintang (2003) consumption of a high protein diet and administration of albumin supplement therapy will increase levels of albumin and TxPA which have better protection against damage to endothelial cells. A study by Kovyrshina (2012) states that albumin is a major protein in the blood which has a vital role in the transport of physiological substances or body metabolites such as fatty acids, hormones, bilirubin and plays an important role in regulating colloid osmolarity of blood plasma. Benny (2003) stated that albumin is the largest protein in blood plasma which plays a role in maintaining blood oncotic pressure (75-80\% plasma osmotic pressure), acting as a transporter of lipophilic substances in the blood. Susetyowati (2006) states that a decrease in albumin levels in the blood can cause fluid to leak out of the blood vessels into the tissues, which causes edema. In preeclampsia, a decrease in albumin levels occurs due to proteinuria and a decrease in the function of the liver and kidneys and the infectious factors that may accompany it.

A study by Amiruddin et al (2007) states that the best diet for preeclamptic patients is a diet high in calories and high in protein, sufficient vitamins, and low in fat, low in salt. Foods oriented to four healthy five perfect with an effort to increase the amount of protein by adding one egg per day. According to Ariyani (2006), eggs are an alternative food ingredient for a useful protein source to help increase serum albumin levels. Eggs are the most complete foodstuff from poultry livestock products in terms of protein, fat, and other nutritional content.

According to Cunningham (2018) Preeclampsia. Until now, the exact etiology is unknown. There are several hypotheses regarding the etiology of preeclampsia, including placental ischemia, immune maladaptation, and genetic factors. Recently, endothelial dysfunction is thought to play a role in the pathogenesis of preeclampsia. Brown Ma et al (2018) stated that Endothelium is the layer of cells lining the vascular wall facing the lumen 


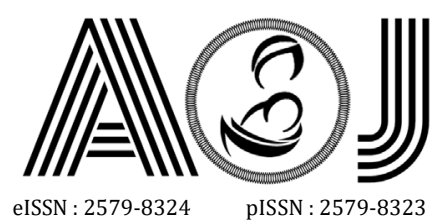

eISSN : 2579-8324
pISSN : 2579-8323

and attached to the subendothelial tissue consisting of collagen and various glycosaminoglycans including fibronectin. It used to be thought that the function of the endothelium is as a structural barrier between circulation and the surrounding tissue, but now it is known that the endothelium regulates vascular tone, prevents thrombosis, regulates the activity of the fibrinolytic system, prevents leukocyte adhesion and regulates vascular growth. If the endothelium is disturbed by various things such as hemodynamic shear stress, oxidative stress, or exposure to inflammatory cytokines and hypercholesterolemia, the regulatory function becomes abnormal and is called endothelial dysfunction. In this situation, there is an imbalance of vasoactive substances so that hypertension can occur. Endothelial dysfunction also causes increased vascular permeability, leading to edema and proteinuria.

According to Al Ghazali et al (2018), proteinuria is one of the markers of preeclampsia, this is related to the incidence of placental ischemia, which will result in local tissue degeneration and release of thromboplastin which subsequently deposition of fibrin in the glomerulus, and increase the permeability of albumin and other plasma proteins.

The results of the research conducted by researchers showed that there was a difference in the effect of giving VipAlbumin sachets and liquid snakehead fish extract for 3 days on serum albumin levels in preeclamptic patients with hypoalbuminemia. VipAlbumin sachets also resulted in a higher increase in albumin levels than liquid snakehead fish extract. These results are similar to research conducted by Kurniawati et al (2017) which states that albumin nanotechnology increases albumin levels higher than albumin capsules, but does not affect the length of treatment days. This research is also supported by the results of research by Purwoko et al () which states that giving Vipalbumin plus is equivalent to $20 \%$ human albumin infusion. Research by Fiza Putra (2017) states that the group given the intervention of processed albumin by the freeze dryer method increased albumin levels by $0.26 \mathrm{gr} / \mathrm{dl}$ ( $\mathrm{p}$ $<0.001)$.

\section{CONCLUSION}

Oral albumin intake provides a significant benefit for increasing serum albumin levels. Freeze dryer sachet method of oral albumin resulted in a higher increase in albumin levels than liquid snakehead fish extract

\section{RECOMMENDATION}

1. It is necessary to determine the procedure for giving oral albumin intake in patients with preeclampsia with hypoalbuminemia.

2. There is a need for further research by assessing serum albumin levels during pregnancy and assessing the factors that cause low albumin levels in pregnancy 


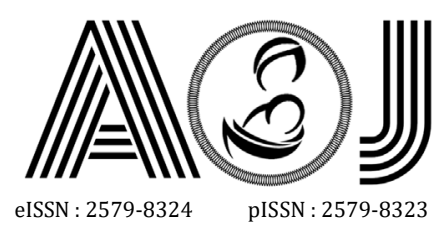

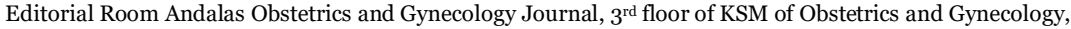
RSUP DR. M. Djamil Padang, Jl. Perintis Kemerdekaan Padang, Sumatera Barat 25127

Website:

http://jurnalobgin.fk.unand.ac.id/index.php/JOE

\section{REFERENCE}

1. Cunningham L, Bloom, Dashe. Hypertensive Disorders. Williams Obstetric 25 ed. New York: Mc Graw Hill; 2017. p. 1086-8

2. Frederic, $T$, Allo, et all. Pengaruh asupan albumin oral (vipalbumin) terhadap kadar albumin serum pada penderita hipoalbuminemia berat pasca laparotomi emergensi di rumah sakit Wahidin Sudirohusodo Makassar. Mei, 2012.

3. Sugio, S, Kashima.A, dkk. Crystal Structure of human serum albumin at $2.5 \mathrm{~A}$ Resolution. Artikel pada : Protein Engineering vol.12. no.6 pp.439-446. Osaka, Jepang.1999

4. Nicholson, JP, Wolmarans, MR, Park, GR. The Role Of Albumin In Critical Illness in Review Article. Br J Anaesth.85 (4). 2000. Pp 599-610

5. Lintang, LS. Gambaran Fraksi Protein Darah Pada Preeklampsia Dan Hamil Normotensif. Tesis Program Magister Kedokteran Klinik-Spesialis IImu Obstetri dan Ginekologi. FK USU. Medan. (Unpublished). 2003

6. Saringat Baie et al : Amino Acid Composition Of Snakehead Fish (Channa Striatus) of Various Sizes Obtained at Different Times of The Year, Malaysian Journal of Pharmaceutical Sciences, Volume 3, Nomor 2, 2005, 19-30, School of Pharmaceutical Sciences, Universiti Sains Malaysia, 11800 USM Pulau Pinang, Malaysia. 2005

7. Chairuddin, B. 2012. Efektivitas Pemberian Kapsul Albumin Ekstrak Ikan Gabus Terhadap Kenaikan Kadar Albumin dalam Darah Pasien Preeklampsia Berat Pasca Seksio Sesarea. Tesis ilmu biomedik , FK UNS. Solo. (unpublished). 2012

8. Hidayanti, H. 2006. Pengaruh Pemberian Kapsul Kosentrat Ikan Gabus pada Pasien Bedah Di RS. Dr. Wahidin Sudirohusodo. Tesis. Program Pascasarjana. (Unpublished).

9. Ulrich Kragh-Hansen, Human Serum Albumin: A Multifunctional Protein, dalam : Albumin in medicine, Pathological and Clinical Applications, Singapore, Springer Science+Business Media, 2016, hal : 1-30

10. Burl R. Don, Kaysent.G, Serum Albumin : Relationship to Inflammation and Nutrition, Seminars in Dialysis, Vol 17, No 6 (November-December), pp. 432-437, 2004

11. Caraceni.P, dkk. Clinical indications for the albumin use: Still a controversial issue. Review article: European Journal of Internal Medicine.Bologna. Italia, 2003

12. Brown MA, Magee LA, Kenny LC, Karumanchi SA, McCarthy FP, Saito S, et al. The hypertensive disorders of pregnancy: ISSHP classification, diagnosis \& management recommendations for international practice. Pregnancy hypertension. 2018;13:291310

13. Butalia S, Audibert F, Cote AM, Firoz T, Logan AG, Magee LA, et al. Hypertension Canada's 2018 Guidelines for the Management of Hypertension in Pregnancy. The Canadian journal of cardiology. 2018;34(5):526-31 


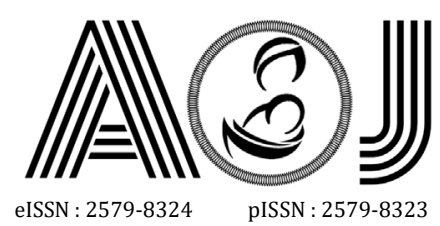

14. Carol Lai M, Stephanie A. Coulter M, Amy Woodruff M. Hypertension and Pregnancy. Texas Heart Institute Journal. 2017;44:350-8

15. Catov JM, Nohr EA, Bodnar LM, Knudson VK, Olsen SF, Olsen J. Association of periconceptional multivitamin use with reduced risk of preeklampsia among normalweight women in the Danish national birth cohort. Am J Epidemiol. 2009;169(11):1304-1311.

16. Chahine KM, Sibai BM. Chronic Hypertension in Pregnancy: New Concepts for Classification and Management. American journal of perinatology. 2018.

17. Kine Marita Knudsen Sand Malin Bern, Jeannette Nilsen, HannaTheodora Noordzij, Unraveling the interaction between FcRn and albumin: opportunities for design of albumin-based therapeutics. Frontiers in Immunology, Volume 5, Article 682. 2015

18. Anraku M, Chuang VTG, Maruyama T, Otagiri M, Redox properties of serum albumin. Biochim Biophys Acta 1830:5465-5472. 2013

19. Silbernagl Stefan, Lang Florian, Kidney Disease in Pregnancy pada Color Atlas of Pathophysiology. Thieme, Stuttgart-Newyork. Hal : 116. 2000.

20. Shapiro M Janet, MD. Critical care of the obstetric patient. J Intensive care Med. 2006; 21: 278-286.

21. Ghanawati-mina abbossi, et al. Review Article Pregnancy and Laboratory studies. A Reference table for clinician. American College of Obsetry and Gynecology. 2009. vol 114 , no. 6.

22. Larsson $A$, et al. Reference value for Clinical Chemistry test during normal pregnancy. BJOG an International journal of Obstetry and gynecology. 2008. 115; 874-881.

23. Anraku M, Shintomo R, Taguchi K, Kragh-Hansen U, Kai T, Maruyama T, Otagiri M. Amino acids of importance for the antioxidant activity of human serum albumin as revealed by recombinant mutants and genetic variants. Life Sci 134:36-41, (2015)

24. Higby K, Suiter C, Phelps J, et al. Normal values of urinary albumin and total protein excretion during pregnancy. Am J Obstet Gynecol 1994;171(4):984-9.

25. Hill C Cristina, MD. Physiologic Changes in Pregnancy. Surgical Clinics of North America. Surg Clin N Am 88 (2008) 391-401.

26. Rahajuningsih Dharma, Noroyono Wibowo, Hessyani P.T. Raranta. Disfungsi Endotel Pada Preeklampsia. Makalah Kesehatan, Vol. 9, No. 2, Desember 2005: 63-69

27. Bienk K, Dagnæs-Hansen F, Wengel J, Kragh-Hansen U, Howard KA. Albumin-mediated protection, reduced immunogenicity and extended circulatory half-life of cholesterol modifi ed small interfering RNA. Presented at the 2015 Annual Meeting of Controlled Release Society, Edinburgh, Scotland, 2015. July 26-29. Abstract 844.

28. Chen Z, He Y, Shi B, Yang D, Human serum albumin from recombinant DNA technology: challenges and strategies. Biochim Biophys Acta.2013. 1830:5515-5525. 


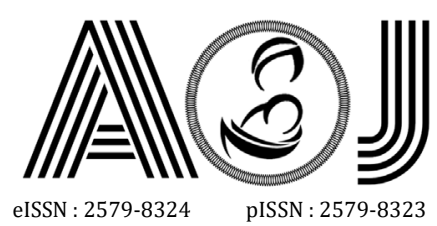

29. Sastroasmoro, S. 2011. Dasar-Dasar Metodologi Penelitian Klinis. Jakarta : Sagung Seto

30. Majorek KA, Porebski PJ, Dayal A, Zimmerman MD, Jablonska K, Stewart AJ, Chruszcz $M$, Minor W, Structural and immunologic characterization of bovine, horse, and rabbit serum albumins. Mol Immunol. 2016. 52:174-182.

31. Mendez CM, McClain CJ, Marsano LS, Albumin therapy in clinical practice. Nutr Clin Pract 20:314-320 Merlot AM, Kalinowski DS, Richardson DR (2014) Unraveling the mysteries of serum albumin-more than just a serum protein. Front Physiol.2005.5:299, Article 299.

32. Arnedo,A., Irache,JM., Merodio,M., Espuelas, M.S. 2004.Albumin Nanoparticles Improved the Stability, Nuclear Accumulation and Anticytomegaloviral Activity of a Phosphodiesteroligonucleotide, 94 (1): 217-227.

33. Minomo A, Ishima Y, Chuang VTG, Suwa Y, Kragh-Hansen U, Narisoko T, Morioka H, Maruyama T, Otagiri $\mathrm{M}$, Albumin domain II mutant with high bilirubin binding affinity has a great potential as serum bilirubin excretion enhancer for hyperbilirubinemia treatment. Biochim Biophys Acta.2013.1830:2917-2923.

34. Preston W George, Plusquin M, et all, Refinement of a Methodology for Untargeted Detection of Serum Albumin Adducts in Human Populations, , Chem. Res. Toxicol.2017.30, 2120-2129, Leuven, Belgium.

35. Mohanraj, V., dan Chen, Y. 2006. Nanoparticles-A Review, Pharmacology Research, 5 (1): 561-573.

36. Vikram Sindgikar, et all. Effect of serum albumin in wound healing and its related complications in surgical patients. US National Library of Medicine enlisted journal. Al Ameen J Med Sc i 2017; 10(2) : 132-135. Al Ameen Charitable Fund Trust, Bangalore.

37. Ana Cristina de Oliveira Gonzalez, et all. Wound healing - A literature review. An Bras Dermatol. Work conducted at the Gonçalo Moniz Research Center - Fundação Oswaldo Cruz (CPqGM/Fiocruz), Salvador, BA, Brazil. 2016;91(5):614-20.

38. Hirotaka Sugino, et all. Relation between the serum albumin level and nutrition supply in patients with pressure ulcer : retrospective study in an acute care setting. The Journal of medical investigation. Tokusihima, Japan. 2014. Vol. 61.

39. Hasan, Irsan, Anggraini T., 2008. Peran Albumin dalam Penatalaksanaan Sirois Hati. Divisi Hepatologi, Departemen IImu Penyakit Dalam FKUI/RSCM -Jakarta.

40. Susetyowati. 2007. Penatalaksanaan Gizi pada Pasien Bedah Digesif. ASDI Semarang: Pertemuan IImiah Nasional III.

41. Gupta,R. dan Kompella, UB., 2006.Nanoparticle Technology for Drug Delivery, Drug and The Pharmaceutical Sciences:159.

42. Nugroho Yudistiro Alit. 2016. Perbandingan Efektivitas terapi Albumin Ekstrak Ikan Gabus Murni dibanding Human Albumin 20\% terhadap Kadar Albumin dan pH Darah 


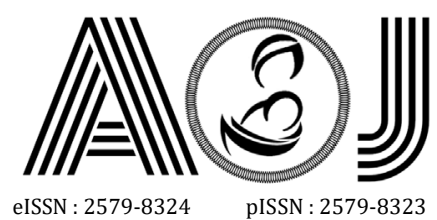

eISSN : 2579-8324

Editorial Room Andalas Obstetrics and Gynecology Journal, $3^{\text {rd }}$ floor of KSM of Obstetrics and Gynecology,

RSUP DR. M. Djamil Padang, Jl. Perintis Kemerdekaan Padang, Sumatera Barat 25127

Pada Pasien Hipoalbuminemia. Tesis Program Studi Ilmu Biomedik (Anastesi), Pascasarjana UNS, Surakarta.

43. Nilesh, J., Ruchi, J., Navneet, T., Brham Prakash, G., Deepak Kumar, J. 2010, Nanotechnology: A Safe and Effective Drug Delivery System, Asian Journal of Pharmaceutical and Clinical Research, 3(3):159-165.

44. Lockman, P.R., Mumper, R.J., Khan, M.A., Allen, D.D. 2002.Nanoparticle Technology for Drug Delivery Across The Blood-brain Barrier, Drug Dev Ind Pharm 28 (1): 1-13

45. Davda, J., Labhasetwar, V. 2002. Characterization on Nanoparticle Uptake by Endothelial Cells, Int J Pharm 233 (1-2):51-59.

46. Simon S, Abustam E, Said MI., 2014. Karakteristik Fungsional Tepung Putih Telur yang Dikeringkan Dengan Freeze Dryer Pada Suhu Dan Ketebalan Berbeda. Skripsi. Fakultas Peternakan. Universitas Hasanudin. Makassar.

47. Gerald Adams. 2007. The Principles of Freeze-Drying. In: Cryopreservation and FreezeDrying, 2nd edition. New Jersey.: 15-38.

48. Yuniarti DW, Sulistiyati TD, Suprayitno E.,2013. Pengaruh Suhu Pengeringan Vakum Terhadap Kualitas Serbuk Albumin Ikan Gabus (Ophiocephalus striatus). THPi Student Journal, Vol 1, 1:1-9

49. Wang, Y., Stavem, K., Dahl, FA., Humerfelt, S., Haugen, T., 2008. Factors Associated with A Prolonged Length of Stay After Acute Exacerbation of Chronic Pulmonary Disease. Int J Chron Obstruct Pulmon Dis, 9; 99-105

50. Delgado, M., Rodriques, Medina, M., Gomez, A., Martinez, G., Mariscal, M., 2002. Cholesterol and Serum Albumin Levels as Predictors of Cross Infection, Death, and Length of Hospital stay, Jama Surgery, 137 (7) ; 805-812

51. Kurniawati, D. 2014. Perbandingan Terapi Albumin Teknologi Nano Dengan Kapsul Albumin Terhadap Peningkatan Kadar Albumin Dan Lama Perawatan. Departemen Anestesiologi Dan Terapi Intensif FK UNS/RSDM-Surakarta. http://dglib.uns.ac.id/dokumen/detail/41262/ALBUMIN-TERHADAP-PENINGKATANKADAR-ALBUMIN-DAN-LAMA-PERAWATAN

52. Al Ghazali Basima, et all. 2014. Study of the clinical significance of serum albumin level in preeklampsia and in the detection of its severity. American Journal of BioMedicine. 2(8): 964-974 